\section{The Value of SCUBE-1 on Ischemia-Reperfusion Model in Diabetic Patients During Knee Replacement Surgery}

\author{
Diz Protezi Cerrahisi Sırasında Diyabetik \\ Hastalarda iskemi-Reperfüzyon Modelindeki \\ SCUBE-1'in Değeri
}

Savaş Altınsoy (1)

Başak Gülel (1)

Derya Özkan (®

Ali Yalçındağ (1)

Lütfiye Tuba Hancı (1)

Aslı Dönmez (1)

\section{ABSTRACT}

Objective: Diabetes Mellitus (DM) is a common disease with high mortality and morbidity worldwide. We aimed to assess the oxidative stress levels in patients with and without DM who underwent knee replacement surgery using a pneumatic tourniquet and investigate whether signal peptide-CUB-EGF domain-containing protein 1 (SCUBE-1) levels are correlated with other ischemia-reperfusion (IR) markers such as malondialdehyde (MDA), and total antioxidant status (TAS).

Method: Patients were assigned into either the diabetic (Group $D ; n=15$ ) or non-diabetic groups (Group C; $n=15)$. MDA, TAS, and SCUBE-1 were assessed at three time points before spinal anesthesia (T1), 5 minutes before (T2) and 2 hours after deflation of the tourniquet (T3).

Results: Demographic variables of the groups were similar. There were no statistically significant differences in SCUBE-1, MDA and TAS levels of both groups at all time points. SCUBE-1 levels were higher at $T 2$ and returned to almost normal levels at T3.

Conclusion: SCUBE-1, MDA and TAS levels increased following tourniquet application and decreased during the reperfusion period. The magnitude of increase, however, didn't differ between patients with or without DM. Our results suggest that SCUBE-1 may be used as a marker of tourniquet-related ischemia-reperfusion model.

Keywords: Diabetes mellitus, ischemia-reperfusion model, malondialdehyde, total antioxidant status, signal peptide-CUB-EGF domain-containing protein 1

Öz

Amaç: Diabetes Mellitus (DM), tüm dünyada yüksek mortalite ve morbiditesi olan yaygın bir hastalıktır. Pnömotik turnike kullanılarak diz protezi ameliyatı yapılan ve DM'i olan ve olmayan hastalar arasındaki oksidatif stres seviyesini belirlemek ve signal peptide-CUB-EGF domaincontaining protein 1 (SCUBE-1) seviyelerinin malondialdehit (MDA) ve total antioksidan durumu (TAS) gibi iskemi reperfüzyon (IR) belirteçleriyle korele olup olmadığını araştırmayı amaçladık. Yöntem: Hastalar diyabetik (grup $D ; n=15$ ) veya diyabetik olmayan ( $g r u p ~ C ; n=15$ ) olarak 2 gruba ayrıldı. MDA, TAS ve SCUBE-1 üç dönemde değerlendirildi: spinal anestezi öncesi (T1), turnike indirilmeden $5 d k$. önce (T2) ve turnike indirildikten 2 saat sonra (T3).

Bulgular: Grupların demografik özellikleri benzerdi. Her 2 grupta da SCUBE-1, MDA ve TAS düzeyleri bakımından tüm zaman dilimlerinde istatistiksel olarak anlamlı fark yoktu. SCUBE-1 seviyeleri T2'de yükseldi ve T3'te neredeyse normal seviyelere döndü.

Sonuç: SCUBE-1, MDA ve TAS seviyeleri turnike uygulamasının ardından arttı ve reperfüzyon döneminde azaldı. Bununla birlikte, artışın derecesi, DM olan veya olmayan hastalar arasında farklılık göstermedi. Sonuçlarımız SCUBE-1'in turnike ile ilişkili iskemi-reperfüzyon modelinin bir belirteci olarak kullanılabileceğini göstermektedir.

Anahtar kelimeler: Diyabetus mellitus, iskemi reperfüzyon modeli, total antioksidan durum, malondialdehit, signal peptide-CUB-EGF domain-containing protein 1
Received: 1 April 2020

Accepted: 30 June 2020 Online First: 30 June 2020

Cite as: Altınsoy S, Gülel B, Özkan D, Yalçındağ A, Hancı LT, Dönmez A. Diz protezi cerrahisi sırasında diyabetik hastalarda iskemi-reperfüzyon modelindeki SCUBE-1'in değeri. JARSS 2020;28(3):150-7.

Savas Altinsoy

Sağlık Bilimleri Üniversitesi

Dışkapı Yıldırım Beyazıt EAH Anesteziyoloji ve Reanimasyon Bölümü, Ankara, Türkiye savasaltinsoy@gmail.com ORCID: 0000-0002-3588-7145

B. Gulel 0000-0002-8679-2023

D. Özkan 0000-0002-8964-3015

A. Dönmez 0000-0002-7378-1632 Sağlık Bilimleri Üniversitesi Dışkapı Yıldırım Beyazıt EAH Anesteziyoloji ve Reanimasyon Bölümü, Ankara, Türkiye

A. Yalçındağ 0000-0003-1846-9248

L. T. Hancı 0000-0001-6367-1117 Sağlık Bilimleri Üniversitesi Dışkapı Yıldırım Beyazıt EAH Klinik Biyokimya Bölümü, Ankara, Türkiye 


\section{INTRODUCTION}

Pneumatic tourniquet is widely used to reduce bleeding and improve surgical visualization in knee replacement surgery. Occlusion of blood flow to the peripheral and impaired tissue oxygenation, however, are important side effects of this application.

Diabetes Mellitus (DM) is a common disease with high mortality and morbidity worldwide. Abnormalities in platelet characteristics in patients with DM can cause platelet hyperactivity which triggers endothelial adhesion and eventually leads to microvascular obstruction and thrombo-inflammation. Due to the impaired oxidative stress response, patients with DM are more prone to ischemia reperfusion (IR) injury related complications (1). This may induce the amplification of the endogenous agonists due to the release of adenosine diphosphate and thromboxane A2 in ischemic organs, and trigger stable thrombus formation and microvascular occlusion (2). Although not fully understood, hyperglycemia is partly considered to be responsible for the underlying mechanism of increased basal oxidative stress ${ }^{(3)}$.

Oxidative stress induces the oxidative damage of biomolecules such as lipids, DNA and proteins. Several molecules such as malondialdehyde (MDA) and 8-hydroxy-2-guanosine (8-OHdg) as well as total antioxidant status (TAS), which reflects the total antioxidant capacity of the organism, have been widely used as biomarkers of oxidative stress ${ }^{(4,5)}$. However, none of these markers proved to be specific for oxidative stress, therefore the search for novel markers continues.

Recently, a new platelet endothelial adhesion molecule, i.e. Signal peptide-CUB-EGF domain-containing protein 1 (SCUBE-1), discovered in the subendothelial matrix of atherosclerotic lesions using immunohistochemical methods, has been introduced as a novel marker of IR ${ }^{(6)}$. SCUBE-1 was increased in patients with acute coronary syndrome and ischemic stroke but not in patients with chronic coronary disorders or in healthy individuals. Furthermore, SCUBE-1 concentration is likely to be related to the severity of ischemia ${ }^{(7)}$.
In the current study, primary outcome was to assess whether SCUBE-1 levels can be used with other IR markers such as malondialdehyde (MDA), and total antioxidant status (TAS) in patients with and without DM during ischemia-reperfusion period. Secondary outcome was to examine the correlation of SCUBE-1 and preoperative serum creatinine $(\mathrm{Cr})$, platelet (PLT), prothrombin time (PT), activated partial thromboplastin time (aPTT), and international normalized ratio (INR) in all periods in both groups.

\section{MATERIAL and METHODS}

\section{Data collection}

We obtained ethical approval from the local ethics committee (ref no:43/08) and registered on ClinicalTrials.gov. All participants' rights were protected and a written informed consent was obtained before the procedures according to the Helsinki Declaration. American Anesthesiology Association (ASA) I-II patients aged between 18-70 years old who underwent knee replacement surgery under spinal anesthesia using a pneumatic tourniquet were enrolled into the study. Patients with a history of cardiorespiratory, renal or bleeding disorders, antiinflammatory drugs treatment, abnormal HbA1c values and cognitive disorders were excluded from the study. Patients who had converted to general anesthesia from spinal anesthesia were excluded. Patients were assigned into either diabetic (Group D; $\mathrm{n}=15$ ) or non-diabetic group (Group C; $\mathrm{n}=15$ ). Diabetic patients were selected from patients who had been diagnosed for at least five years and were receiving insulin therapy or oral antidiabetic therapy. None of the patients received premedication.

Demographic features including age, gender, height, weight, BMI (Body mass index), HbA1c, blood glucose values (FBG), Cr, PLT, PT, aPTT, INR values and ASA status as well as the duration of tourniquet use and surgery were recorded. In the operation room, patients were followed using standard anesthesia monitoring comprising 5-channel electrocardiogram (ECG), peripheral oxygen saturation $\left(\mathrm{SpO}_{2}\right)$ and noninvasive blood pressure monitoring. Anesthesia was performed in the lateral decubitus position at the L3-L4 level using a 25G Quincke spinal needle (Spinocan ${ }^{\circledast}$, Braun, Melsungen, Germany) and 0.5\% 10-12.5 mg Marcaine Heavysolution (Marcaine ${ }^{\circledR}$ Spinal 
Heavy 0.5\% Ampul, Astra Zeneca, Sweden). After spinal anesthesia, tourniquet was inflated to a pressure of $150 \mathrm{mmHg}$ above systolic blood pressure.

Hypotension was described as more than 20\% decrease from baseline mean blood pressure and / or as a systolic blood pressure below $90 \mathrm{mmHg}$. Bradycardia was described as heart rate below 50 bpm. Hypotension was treated with ephedrine $5 \mathrm{mg}$ and bradycardia with atropine $0.5 \mathrm{mg}$.

\section{Biochemical methods}

MDA, TAS and SCUBE-1 levels were assessed at three time points: before spinal anesthesia (T1), 5 minutes before deflation of the tourniquet (ischemia T2) and 2 hours after deflation of the tourniquet (reperfusion T3) ${ }^{(8)}$.

Peripheral venous blood samples were collected from all patients by venipuncture in serum separator tubes to avoid hemolysis. They were centrifuged at $3500 \mathrm{rpm}$ for $10 \mathrm{~min}$ and the sera was separated and stored at $-20^{\circ} \mathrm{C}$ until analysis. All measurements were performed using the Diasorin Eti-max 3000 analyzer (Milan-Italy).

\section{Total antioxidant status}

TAS was measured by colorimetric method defined by Erel using the total antioxidant status assay kit (Rel Assay Diagnostic, Turkey) ${ }^{(9)}$. The method was based on the reduction of colored 2,2'-azino-bis (3ethylbenzotiazoline-6-sulfonic acid) radical to a colourless reduced form by antioxidant present in human serum samples. The change of absorbance at $660 \mathrm{~nm}$ is related with total antioxidant level of the sample. The assay was calibrated with a stable antioxidant standard solution which is traditionally named as Trolox Equivalent that is a vitamin E analog. The assay results are expressed as mmol Trolox Equiv. L-1 (assay range 0.1 and 3.5).

\section{Malondialdehyde}

MDA was measured by enzyme-linked immunosorbent assay (ELISA) method using a special kit (Sunred Biological Technology Co. Ltd, Cat. No: 201-12-1372 Shanghai, China). The kit was used a double-antibody sandwich ELISA to assay the level of MDA in human serum samples. We added MDA to monoclonal antibody enzyme well which is pre-coated with human MDA monoclonal antibody, incubation; then added MDA antibodies labelled with biotin, and combined with Streptavidin-HRP to form immune complex. Afterwards we carried out incubation and washing procedures again to remove the uncombined enzyme. When Chromogen Solution A and B were added blue color changed to yellow. Finally, optical density (OD) was measured under $450 \mathrm{~nm}$ wavelength. According to concentration of the standards and the corresponding OD values, we formulated the standard curve linear regression equation, and then applied the OD values of the sample on the regression equation to calculate the concentration of the corresponding sample. The sensitivity of this assay is $0.515 \mathrm{nmol} \mathrm{mL}^{-1}$ which was defined as the lowest protein concentration that could be differentiated from zero. The assay results are expressed as $\mathrm{nmol} / \mathrm{mL}$ (assay range 0.75 and 100 ).

\section{Signal peptide-CUB-EGF domain-containing protein 1 (SCUBE-1)}

SCUBE-1 was measured by ELISA method using a special kit (Sunred Biological Technology Co. Ltd, Cat. No: 201-12-5378 Shanghai, China). The kit of a double-antibody sandwich ELISA method was used to assay the level of SCUBE-1 in human serum samples. SCUBE-1 was added to monoclonal antibody enzyme well which is pre-coated with human SCUBE-1 monoclonal antibody then SCUBE-1 antibodies labeled with biotin, and combined with Streptavidin-HRP to form immune complex; were added to carry out incubation. Afterwards uncombined enzyme was washed out and eliminated ag. When Chromogen Solution A and B were added blue color changed to yellow. Finally, OD was measured under $450 \mathrm{~nm}$ wavelength. According to concentration of the standard and the corresponding OD values, we formulated the standard curve linear regression equation, and then applied the OD values of the sample on the regression equation to calculate the concentration of the corresponding sample. The sensitivity of this assay is $0.852 \mathrm{ng} / \mathrm{mL}$ which is defined as the lowest protein concentration that can be differentiated from zero. The assay results are expressed as $\mathrm{ng} \mathrm{mL}^{-1}$ (assay range 1-300).

\section{Other measurements}

PLT, PT, aPTT, and blood glucose values were assessed at preoperative period. PT and aPTT levels were 
determined by photometric method using ACL TOP 700 system Instrumentation Laboratory (Kirchheim, Germany) by quantitative measurement. Glucose and creatinine were studied by photometric method in Beckman Coulter AU5800.

\section{Statistical analysis}

The sample size of the study were calculated with G*Power (G*Power Ver. 3.1.9.2, Franz Faul, Üniversität Kiel, Germany, https://www.gpower.hhu. de) program. The sample size was calculated with the effect size of 0.3 , alpha $=0.05$ and power $=0.90$ for 3 repeated measurements in 2 groups and total number of 26 samples were determined. So, 30 patients were enrolled for possible dropouts in both groups. We used the SPSS 21.0 (SPSS, Inc, Chicago, IL, USA) statistical program for statistical analyses. Categorical data were compared using the chisquare or Fisher absolute test. Data were tested for normality using the Shapiro-Wilk test. Statistical analyses were performed with Student's t-test or analyses of variance for multiple comparisons and Bonferrroni correction for post-hoc analysis, the $\chi^{2}$ test or Mann- Whitney U test as appropriate. Pearson Correlation test were used to determine how one variable was affected by another variable. Statistical significance was set at $p<0.05$.

\section{RESULTS}

All patients completed the study. Groups were well matched in terms of age, gender, ASA, BMI, duration

Table I. Demographic data

\begin{tabular}{lccc}
\hline & $\begin{array}{c}\text { Group D } \\
\text { (n:15) }\end{array}$ & $\begin{array}{c}\text { Group C } \\
\text { (n:15) }\end{array}$ & p \\
\hline Age $(\mathrm{yr})$ & $66.13 \pm 6.86$ & $64.66 \pm 9.98$ & 0.64 \\
Gender F/M (n) & $9 / 6$ & $8 / 7$ & 0.713 \\
BMI $\left(\mathrm{kg} \mathrm{m}^{-2}\right)$ & $31.38 \pm 4.56$ & $30.64 \pm 4.41$ & 0.652 \\
ASA I/II (n) & $9 / 6$ & $7 / 8$ & 0.464 \\
Creatinine $\left(\mathrm{mg} \mathrm{dL}^{-1}\right)$ & $0.87 \pm 0.14$ & $0.94 \pm 0.10$ & 0.093 \\
Platelet $\left(\mu \mathrm{g} \mathrm{L}^{-1}\right)$ & $325066 \pm 70431$ & $332600 \pm 68030$ & 0.768 \\
PT (sec) & $11.48 \pm 0.59$ & $11.34 \pm 0.67$ & 0.405 \\
aPTT (sec) & $28.07 \pm 2.5$ & $28.38 \pm 2.3$ & 0.540 \\
INR & $0.98 \pm 0.05$ & $1.00 \pm 0.08$ & 0.739 \\
Duration of Surgery (min) & $84.67 \pm 23.56$ & $92 \pm 17.7$ & 0.310 \\
Duration of Tourniquet (min) & $63.33 \pm 21.18$ & $70 \pm 13.09$ & 0.344 \\
Glucose (mg dL ${ }^{-1}$ ) & $97.6 \pm 9.6$ & $97.1 \pm 8.9$ & 0.891 \\
& & &
\end{tabular}

BMI: Body mass index, ASA: American Society of Anesthesiologists Status, F: Female, M: Male, PT: Prothrombin time, aPTT: Activated partial thromboplastin time, INR: International normalized ratio of tourniquet use and surgery (Table I). None of the patients developed hypotension or bradycardia after or during anesthesia so none of the patients required atropine or ephedrine. In both groups, glucose and $\mathrm{HbA1c}$ levels were within normal limits. The level of spinal anesthesia in both groups was below T10 dermatome. The cuff pressure of tourniquet was $260 \pm 13.5 \mathrm{mmHg}$ and $270 \pm 14.5 \mathrm{mmHg}$ in Group D and $C$, respectively $(p=0.982)$.

We did not observe a significant difference in SCUBE $1(p=0.363, p=0.383$ and $p=0.285), \operatorname{MDA}(p=0.631$, 0.641 and 0.617$)$ and TAS ( $p=0.446, p=0392$ and $\mathrm{p}=0.870$ ) levels between the groups in $\mathrm{T} 1, \mathrm{~T} 2$ and $\mathrm{T} 3$ time points, respectively. SCUBE 1, MDA and TAS levels were increased at $T 2$ according to the baseline levels ( $p=0.001, p=0.023$ and $p=0.032$, respectively), and returned close to baseline levels at $\mathrm{T} 3$ in both groups (Figure 1,2,3). MDA and TAS levels were correlated with SCUBE-1 at all the three time points in both groups $(p=0.002)$. Correlation of SCUBE-1 levels with platelet, creatinine, PT, aPTT and INR measurements are given in Table II. Platelet counts were $325066 \pm 70431$ vs $332600 \pm 68030 \mathrm{~mm}^{3} \mathrm{dL}^{-1}$, creatinine was $0.87 \pm 0.14$ vs $0.94 \pm 0.10 \mathrm{mg} \mathrm{dL}{ }^{-1}$, PT $11.48 \pm 0.59$ vs $11.34 \pm 0.67 \mathrm{sec}$, aPTT $28.07 \pm 2.5$ vs $28.38 \pm 2.3 \mathrm{sec}$ and INR $0.98 \pm 0.05$ vs $1.00 \pm 0.08$ in Groups $D$ and $C$ respectively. Creatinine value in $T 1$ period showed a weak, insignificantly negative correlation with SCUBE-1. There was no significant correlation between PLT, PT, aPTT, INR and SCUBE-1 measurements on T1, T2 and T3 time points (Table II).

Table II. Correlations between laboratory values and SCUBE-1

\begin{tabular}{lccc}
\hline & \multicolumn{3}{c}{ SCUBE-1 values } \\
\cline { 2 - 4 } & T1 & T2 & T3 \\
\hline Platelet & $\mathrm{r}: 0.288$ & $\mathrm{r}: 0.286$ & $\mathrm{r}: 0.222$ \\
& $\mathrm{p}: 0.123$ & $\mathrm{p}: 0.126$ & $\mathrm{p}: 0.238$ \\
Creatinine & $\mathrm{r}:-0.025$ & $\mathrm{r}: 0.019$ & $\mathrm{r}: 0.058$ \\
& $\mathrm{p}: 0.897$ & $\mathrm{p}: 0.921$ & $\mathrm{p}: 0.761$ \\
PT & $\mathrm{r}: 0.278$ & $\mathrm{r}: 0.310$ & $\mathrm{r}: 0.252$ \\
& $\mathrm{p}: 0.136$ & $\mathrm{p}: 0.096$ & $\mathrm{p}: 0.180$ \\
aPTT & $\mathrm{r}: 0.010$ & $\mathrm{r}: 0.033$ & $\mathrm{r}:-0.121$ \\
& $\mathrm{p}: 0.960$ & $\mathrm{p}: 0.863$ & $\mathrm{p}: 0.524$ \\
INR & $\mathrm{r}: 0.124$ & $\mathrm{r}: 0.134$ & $\mathrm{r}: 0.114$ \\
& $\mathrm{p}: 0.513$ & $\mathrm{p}: 0.480$ & $\mathrm{p}: 0.550$ \\
\hline
\end{tabular}

PT: Prothrombin time, aPTT: Activated partial thromboplastin time, INR: International normalized ratio 


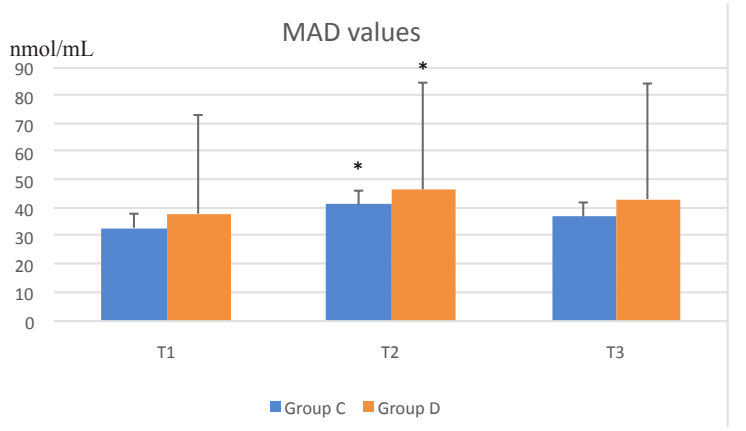

Figure 1. Malondialdehyde (MDA) values (T1; baseline period, T2; ischemic period, T3; reperfusion period. * $p=0.002$ compared with preischemic values in both groups (T1)

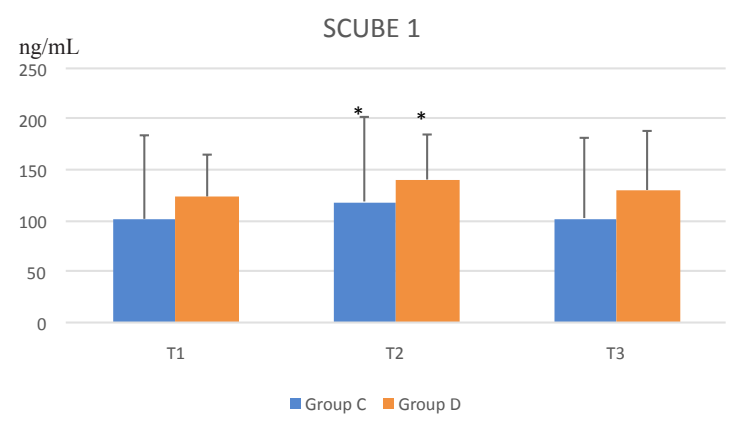

Figure 2. Signal peptide-CUB-EGF domain-containing protein 1 (SCUBE 1) values (T1; baseline period, T2; ischemic period, T3; reperfusion period. ${ }^{*} \mathrm{p}=0.001$ compared with preischemic values in both groups (T1)

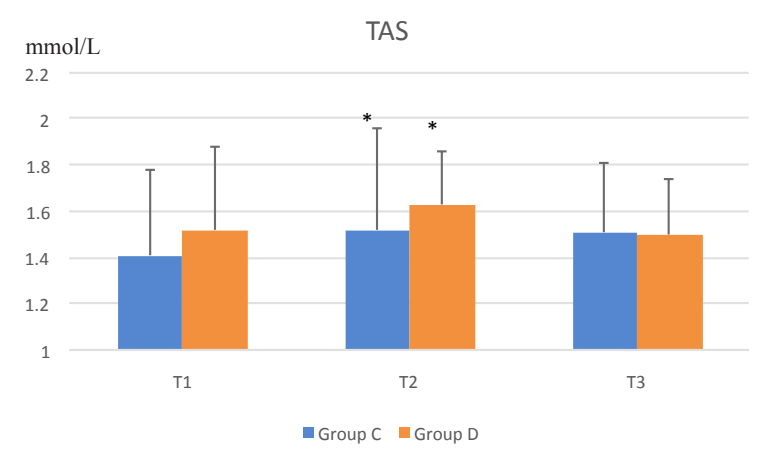

Figure 3. Total antioxidant status (TAS) (T1; baseline period, T2; ischemic period, T3; reperfusion period. ${ }^{*} \mathrm{p}=0.032$ compared with preischemic values in both groups (T1)

\section{DISCUSSION}

Our results suggest that SCUBE-1 may be used as a marker of tourniquet-related ischemia-reperfusion injury. SCUBE-1 concentration increased following tourniquet application in patients who underwent knee replacement surgery and returned to normal levels during the reperfusion period. The degree of increase, however, did not differ between patients with or without DM.

IR injury is a well-established phenomenon. Extremity surgery using a pneumatic tourniquet is a good model. The use of a pneumatic tourniquet during extremity operations is associated with mechanical muscle and nerve injury during the inflation period and with IR injury during the deflation period ${ }^{(10,11)}$. Although there are many studies on IR injury in the literature, there is no consensus on sampling timing. Different results were obtained from the studies on samples taken in various time periods.
IR injury leads to cellular damage and free radical formation which trigger lipid peroxidation and MDA release. MDA has been used as an indicator of free radical formation for many years ${ }^{(12,13)}$. Omer et al. ${ }^{(14)}$ recently studied MDA in a tourniquet-induced IR model. They measured MDA levels 5 min before and $30 \mathrm{~min}$ after deflation and found an increase during the IR period. MDA levels during the ischemic period also increased in our study consistent with the literature. However, MDA levels decreased 2 hrs after tourniquet deflation. Our sampling time might affect our results.

The antioxidant defense system includes enzymes such as superoxide dismutase (SOD), catalase (CAT) and glutathione peroxidase (GPX). TAS is a measure of the total antioxidant capacity of a sample ${ }^{(9,15)}$. Unless the oxidant system is activated, TAS remains normal ${ }^{(16)}$. Balance between the oxidation and antioxidation system is important for maintaining cell and tissue structure and function. A study has 
showed that short periods of ischemic stress may produce an adaptive response in the tissues ${ }^{(17)}$. On the other hand, tourniquet application stops macroscopic blood flow but does not stop intramedullary blood flow which may affect TAS levels ${ }^{(18)}$. In the current study, TAS levels increased 5 minutes before tourniquet deflation and returned to normal levels at $2 \mathrm{~h}$ after tourniquet deflation. Even though the mechanism is not fully clear it is possible that increased TAS values may reflect upregulation of the antioxidant defense system to cellular oxidative stress or compensatory mechanisms during the ischemic period may be involved. Both increased MDA and TAS levels indicate development of IR injury with tourniquet application in our study. Studies on ischemia / reperfusion have shown that following reperfusion and increased oxidative stress, total antioxidant capacity decreases due to consumption of some enzymes $(16,19,20)$. In response to increased production of free radicals during the reperfusion, antioxidant enzymes (SOD, CAT, and GSH-Px) increase to contribute to the antioxidative defense system. If the free radical production persists for a long time, the antioxidant enzymes (SOD, CAT, GSH-Px) may be broken down by free radicals (21). Consistently, this may explain the decrease in TAS levels 2 hours after deflation of the tourniquet (T3) in the current study.

SCUBE-1 is a surface protein expressed during development and particularly in the endothelium and platelets. It has previously been studied in several ischemic conditions including acute ischemic stroke, acute coronary syndrome and acute mesenteric ischemia; as well as in autoimmune disorders such as Hashimato thyroiditis and psoriasis ${ }^{(7,22,23)}$. Although some claim the opposite, SCUBE-1 has been shown to correlate well with MDA and TAS.

Dai et al. ${ }^{(6)}$ concluded that plasma SCUBE1 was obtained from platelets stimulated via proteolytic division and can play pathological roles by facilitating platelet adhesion/agglutination and subsequent thrombus formation. In a study, prothrombin time, active thromboplastin time, factor $7 c-8 c$, antithrombin 3 and plasminogen levels were measured in diabetic patients. aPTT levels in both men and women were lower in diabetics group than the control group. As a result, it was reported that diabetic patients are prone to coagulation ${ }^{(24)}$. Günaydın et al. ${ }^{(7)}$ studied the relationship between creatinine, aPTT, PT, INR and platelet level and SCUBE-1. They only showed negative correlation between platelet counts and SCUBE-1 level in acute ischemic stroke. In the current study, there was no correlation between SCUBE-1 level and Cr, PLT, aPTT, PT and INR levels. It is our preference to perform surgery under anesthesia in patients with regulated DM. This might have affected our results, since wellregulated DM patients with normal HbA1C levels are expected to have less systemic end-organ effects.

The ideal tourniquet time is controversial. Although 1-3 hours is usually accepted as safe, Rasmussen et al. ${ }^{(11)}$ showed that tissue damage starts as soon as 15 minutes following tourniquet application. In the current study, to ensure standardization, we set the tourniquet time between 30 and 90 minutes. Thus, all patients developed tourniquet-related tissue damage within safe limits. The fact that MAD, TAS and SCUBE-1 concentrations returned to nearly normal, right after tourniquet deflation, further supports this assumption.

To the best of our knowledge, there are no clinical studies which have previously assessed SCUBE-1 as an oxidative stress marker in a clinical model of DM and / or tourniquet-induced ischemia-reperfusion injury. In the current study, although tourniquet-related ischemia time was shorter than 2 hours, SCUBE 1 concentrations were increased in both groups. Of note, the degree of increase did not differ between patients with or without DM. In the current study, all patients underwent elective surgery; thus, they had good blood glucose regulation and $\mathrm{HbA1c}$ levels were within the normal range. The absence of a significant difference in the levels of oxidant and antioxidant markers between patients with and without DM may be due to the similarities inHbA1c levels between the groups ${ }^{(25)}$.

Diabetes is associated with an increase in pro-inflammatory cells. Cytosolic calcium levels in the circulating platelets of patients with DM are higher than normal individuals. Consequently, antioxidant levels decrease and oxidative stress increases. Acute hyperglycemia and ROS formation are also impor- 
tant causes of increased platelet activation (1). Patients with DM have an increased risk of thrombosis and related complications. It has been revealed that hyperglycemia impairs oxidative stress response (2). Since duration of the disease is related with these adverse effects, we conducted our study in patients with DM lasting for at least 5 years.

General and spinal anesthesia are used extensively in knee replacement surgery. Neuraxial blockade especially spinal anesthesia has been shown to be safer in this respect with a low risk of thromboembolism, intraoperative bleeding, postoperative pain, risk of surgical site infection and morbidity ${ }^{(26-28)}$. Due to its possible positive contribution to ischemia-reperfusion damage we used spinal anesthesia instead of general anesthesia.

There are some limitations of this study. Guidelines recommend to have preoperative $\mathrm{HbA} 1 \mathrm{c}$ levels below $7 \%$ and blood glucose levels between $80-180$ $\mathrm{mg} \mathrm{dL}^{-1}$ in patients with DM for elective operations ${ }^{(29)}$. In the current study, patients were scheduled to undergo elective surgery, therefore, they had good glycemic regulation. This probably accounted for the absence of a significant difference in SCUBE-1 and IR injury markers between patients with and without DM. Future studies in patients with poor glycemic control may reveal different results. There are several/different time periods for determination of IRI in various studies. Of these we chose the period 2 hrs after deflation ${ }^{(8)}$. Still some more studies are needed in this respect.

\section{CONCLUSION}

To conclude, in this study SCUBE-1 increased during tourniquet-induced ischemia with or without diabetic patients, so it is suitable to use SCUBE-1 as a follow up marker. Also, there was no significant correlation between preoperative PLT, $\mathrm{Cr}$, PT, aPTT and INR values with SCUBE-1 levels in both groups.

Acknowledgments: There was no assistance with the study and no financial support and sponsorship.
Ethics Committee Approval: Ethical approval were obtained from the Ethics Committee of the University of Health Sciences, Diskapi Yildirim Beyazit Training and Research Hospital (ref no: 43/08) and registered the clinicaltrials.gov (NCT03389607)

Conflict of Interest: There is no financial relationship with a biotechnology and/or pharmaceutical manufacturer that has an interest in the subject matter or materials discussed in the submitted manuscript. None of the authors have no conflict of interest to disclose

Funding: This research did not receive any specific grant from funding agencies in the public, commercial, or not-for-profit sectors

Informed Consent: A written informed consent was obtained from all patients

\section{REFERENCES}

1. Lejay A, Fang F, John $R$, et al. Ischemia reperfusion injury, ischemic conditioning and diabetes mellitus. J Mol Cell Cardiol. 2016;91:11-22.

https://doi.org/10.1016/j.yjmcc.2015.12.020

2. Maiocchi S, Alwis I, Wu MCL, Yuan Y, Jackson SP. Thromboinflammatory Functions of Platelets in Ischemia-Reperfusion Injury and Its Dysregulation in Diabetes. Semin Thromb Hemost. 2018;44:102-13. https://doi.org/10.1055/s-0037-1613694

3. Rehni AK, Dave KR. Ameliorative potential of conditioning on ischemia-reperfusion injury in diabetes. Cond Med. 2018;1:105-15.

4. Dilber Y, Inan S, Ercan GA, Sencan A. The role of CAPE in PI3K/AKT/mTOR activation and oxidative stress on testis torsion. Acta Histochem. 2016;118:31-7. https://doi.org/10.1016/j.acthis.2015.11.004

5. Chen KH, Hsiang EL, Hsu MY, et al. Elevation of serum oxidative stress in patients with retina vein occlusions. Acta Ophthalmol. 2018. https://doi.org/10.1111/aos.13892

6. Dai DF, Thajeb P, Tu CF, et al. Plasma concentration of SCUBE1, a novel platelet protein, is elevated in patients with acute coronary syndrome and ischemic stroke. J Am Coll Cardiol. 2008;51:2173-80. https://doi.org/10.1016/j.jacc.2008.01.060

7. Günaydın M ShTr, Sahin A. The diagnostic value of SCUBE1 levels in acute ischemic stroke. Türk Biyokimya Dergisi. Turkish Journal of Biochemistry-Turk J Biochem. 2014;39:107-12. https://doi.org/10.5505/tjb.2014.43534

8. Ozkan D, Akkaya T, Yalcindag A, et al. Propofol sedation in total knee replacement: effects on oxidative stress and ischemia-reperfusion damage. Anaesthesist. 2013;62:537-42.

https://doi.org/10.1007/s00101-013-2192-8

9. Erel O. A novel automated method to measure total antioxidant response against potent free radical reactions. Clin Biochem. 2004;37:112-9. 
https://doi.org/10.1016/j.clinbiochem.2003.10.014

10. Mayer C, Franz A, Harmsen JF, et al. Soft-tissue damage during total knee arthroplasty: Focus on tourniquetinduced metabolic and ionic muscle impairment. J Orthop. 2017;14:347-53.

https://doi.org/10.1016/j.jor.2017.06.015

11. Rasmussen LE, Holm HA, Kristensen PW, KjaersgaardAndersen P. Tourniquet time in total knee arthroplasty. Knee. 2018;25:306-13. https://doi.org/10.1016/j.knee.2018.01.002

12. Russo I, Penna C, Musso T, et al. Platelets, diabetes and myocardial ischemia/reperfusion injury. Cardiovasc Diabetol. 2017;16:71. https://doi.org/10.1186/s12933-017-0550-6

13. Kosucu M, Coskun I, Eroglu A, et al. The effects of spinal, inhalation, and total intravenous anesthetic techniques on ischemia-reperfusion injury in arthroscopic knee surgery. Biomed Res Int. 2014;2014:846570. https://doi.org/10.1155/2014/846570

14. Omer K, Nermin G, Ali A, et al. Tourniquet-induced ischaemia-reperfusion injury: the comparison of antioxidative effects of small-dose propofol and ketamine. Rev Bras Anestesiol. 2017;67:246-50. https://doi.org/10.1016/j.bjan.2016.10.007

15. Gutteridge JMC, Halliwell B. Mini-Review: Oxidative stress, redox stress or redox success? Biochem Biophys Res Commun. 2018;502:183-6. https://doi.org/10.1016/j.bbrc.2018.05.045

16. Erel O. A novel automated direct measurement method for total antioxidant capacity using a new generation, more stable ABTS radical cation. Clin Biochem. 2004;37:277-85. https://doi.org/10.1016/j.clinbiochem.2003.11.015

17. Baldrick FR, McFadden $K$, Ibars $M$, et al. Impact of a (poly)phenol-rich extract from the brown algae Ascophyllum nodosum on DNA damage and antioxidant activity in an overweight or obese population: a randomized controlled trial. Am J Clin Nutr. 2018;108:688-700. https://doi.org/10.1093/ajcn/nqy147

18. Parratt JR. Protection of the heart by ischaemic preconditioning: mechanisms and possibilities for pharmacological exploitation. Trends Pharmacol Sci. 1994;15:1925.

https://doi.org/10.1016/0165-6147(94)90129-5

19. Estebe JP, Davies JM, Richebe P. The pneumatic tourniquet: mechanical, ischaemia-reperfusion and systemic effects. Eur J Anaesthesiol. 2011;28:404-11.
https://doi.org/10.1097/EJA.0b013e328346d5a9

20. Thorat VN, Suryakar AN, Naik P, Tiwale BM. Total antioxidant capacity and lipid peroxidation in liver transplantation. Indian J Clin Biochem. 2009;24:102-4. https://doi.org/10.1007/s12291-009-0018-x

21. Koca K, Yurttas $Y$, Cayci T, et al. The role of preconditioning and $\mathrm{N}$-acetylcysteine on oxidative stress resulting from tourniquet-induced ischemia-reperfusion in arthroscopic knee surgery. J Trauma. 2011;70:717-23. https://doi.org/10.1097/TA.0b013e3181f30fb0

22. Bilir B, Soysal-Atile N, Bilir E, et al. Evaluation of SCUBE-1 and SCD40L biomarkers in patients with hypothyroidism due to Hashimoto's thyroiditis: a singleblind, controlled clinical study. Eur Rev Med Pharmacol Sci. 2016;20:407-13.

23. Turkmen S, Eryigit U, Karaca $Y$, et al. Diagnostic value of plasma signal peptide-Cub-Egf domain-containing protein-1 (SCUBE-1) in an experimental model of acute ischemic stroke. Am J Emerg Med. 2015;33:262-5. https://doi.org/10.1016/j.ajem.2014.11.051

24. Chan P, Pan WH. Coagulation activation in type 2 diabetes mellitus: the higher coronary risk of female diabetic patients. Diabet Med. 1995;12:504-7. https://doi.org/10.1111/j.1464-5491.1995.tb00532.x

25. Yin J, Jin D, Wang H. Serum glycated albumin is superior to hemoglobin A1c for correlating with HMGB1 in coronary artery disease with type 2 diabetic mellitus patients. Int J Clin Exp Med. 2015;8:4821-5.

26. Nakamura M, Kamei M, Bito S, et al. Spinal anesthesia increases the risk of venous thromboembolism in total arthroplasty: Secondary analysis of a J-PSVT cohort study on anesthesia. Medicine (Baltimore). 2017;96:e6748. https://doi.org/10.1097/MD.0000000000006748

27. Perlas A, Chan VW, Beattie S. Anesthesia Technique and Mortality after Total Hip or Knee Arthroplasty: A Retrospective, Propensity Score-matched Cohort Study. Anesthesiology. 2016;125:724-31. https://doi.org/10.1097/ALN.0000000000001248

28. Gottschalk A, Rink B, Smektala R, Piontek A, Ellger B, Gottschalk A. Spinal anesthesia protects against perioperative hyperglycemia in patients undergoing hip arthroplasty. J Clin Anesth. 2014;26:455-60. https://doi.org/10.1016/j.jclinane.2014.02.001

29. Duggan EW, Carlson K, Umpierrez GE. Perioperative Hyperglycemia Management: An Update. Anesthesiology. 2017;126:547-60. https://doi.org/10.1097/ALN.0000000000001515 